a case for safe non-steroidal anti-inflammatory or analgesic drugs being available over the counter, the medical profession should be aware of them. Doctors prescribe assuming that treatment will not be duplicated and that potential toxicity and inappropriate combinations of drugs will be avoided.

No $\left({ }^{\circ}{ }_{0}\right)$ of correct answers from 93 questionnaires

\begin{tabular}{|c|c|c|c|}
\hline Proprietary names & Contents & $\begin{array}{l}\text { Recognised as being } \\
\text { available over the } \\
\text { counter }\end{array}$ & Contents known \\
\hline $\begin{array}{l}\text { Triadol } \\
\text { Nurofen } \\
\text { Proflex } \\
\text { Maxagesic } \\
\text { Phensic }\end{array}$ & $\begin{array}{l}\text { Benorylate } \\
\text { Ibuprofen } \\
\text { Ibuprofen } \\
\text { Ibuprofen } \\
\text { Aspirin }\end{array}$ & $\begin{array}{c}16(17 \cdot 2) \\
61(65 \cdot 6) \\
26(28 \cdot 0) \\
8(8 \cdot 6) \\
93(100)\end{array}$ & $\begin{array}{c}13(14.0) \\
57(61 \cdot 2) \\
6(6.5) \\
2(2 \cdot 2) \\
66(71 \cdot 0)\end{array}$ \\
\hline
\end{tabular}

We sought the views of rheumatologists because they often prescribe non-steroidal anti-inflammatory drugs. Most were not aware that benorylate is available over the counter. Only Nurofen and Phensic were recognised as being available without prescription, possibly because they have been advertised widely. Preparations of paracetamol and aspirin have been available over the counter longer and can produce problems if doctors are unaware that they are being taken. Lack of awareness is compounded by the multiplicity of brand names under which these drugs are marketed. Although the use of alternative brand names allows public promotion without incurring the wrath of the medical profession, it does lead to potential duplicate prescribing. None of the usual texts used by clinicians lists these preparations.

If the trend is to make more non-steroidal anti-inflammatory and other drugs available over the counter, the medical profession should be aware of this. Inclusion of such drugs in the usual reference texts, such as Monthly Index of Medical Specialties (MIMS), British National Formulary, and Data Sheet Compendium would help rational prescribing.

Anonymous. Non-steroidal anti-inflammatory drugs: have we been spoilt for
choice? [Editorial.] Lancet 1984;i:141-2. choice? [Editorial.] Lancet $1984 ; 1: 141-2$.

Gham C, Jayson MIV. Non-prescribed treatments in rheumatic patients. Ann Accepted 1 fune 1984)

Staffordshire Rheumatology Centre, Haywood Hospital, Burslem,

Stoke-on-Trent, Staffordshire ST6 7AG

P T DAWES, MRCP, senior registrar

P D FOWLER, MB, clinical assistant

M F SHADFORTH, MRCP, consultant rheumatologist

T E HOTHERSALL, FRCP, consultant rheumatologist

Correspondence to: Dr P T Dawes.

\section{Formed visual hallucinations with pituitary adenomas}

Visual hallucinations were first reported in patients with pituitary adenomas in $1940 .{ }^{1}$ Nevertheless, these are thought to be rare ${ }^{2}$ and none were found in 260 patients with pituitary adenomas examined specifically for neuro-ophthalmological abnormality. ${ }^{3}$ We report three patients with proved chromophobe adenomas in whom formed visual hallucinations were prominent symptoms.

\section{Case reports}

Case 1-A 54 year old man presented in 1978 with two years' worsening vision. For three months each evening plastic water filled bags in the shape of human faces had appeared in his temporal visual fields, floated away, and vanished. They were suppressed by thioridazine. He showed clinical hypopituitarism, bitemporal hemianopia, and left optic atrophy. Visual acuity was $6 / 9$ (right) and $6 / 12$ (left). Computed tomography showed a $3.5 \mathrm{~cm}$ pituitary tumour with suprasellar extension deforming the third ventricle. The $9 \mathrm{am}$ cortisol value was $80 \mathrm{nmol} 1(2.9 \mu \mathrm{g} / 100 \mathrm{ml}$ ) (normal $170-760(6 \cdot 2-27 \cdot 6 \mu \mathrm{g} / 100 \mathrm{ml}))$, thyroxine $67 \mathrm{nmol} 1(5 \cdot 2 \mu \mathrm{g} 100 \mathrm{ml})(60-170$ $(4 \cdot 7-13 \cdot 2 \mu \mathrm{g} / 100 \mathrm{ml})$ ), and prolactin $367 \mathrm{mU} /(<220)$. Dynamic tests of pituitary function were not performed. Surgical excision of a chromophobe adenoma and external pituitary irradiation led to remission of the hallucinations.

Case 2-In 1968 a 54 year old woman, well since the incomplete removal of a chromophobe adenoma 12 years previously, presented with personality change and violent behaviour. Whenever she closed her eyes she saw hundreds of toothless human faces. Her memory was normal, but she was disinhibited and disorientated in time and place, with dyscalculia and constructional apraxia. Visual acuity was J16 (right), J20 (left) and there was a right temporal hemianopia. Air encephalography showed a large intrasellar mass with right parasellar extension to the frontal lobe but she refused reoperation. Treatment with cortisone and thyroxine was started, but despite a normal protein bound iodine concentration (197 nmol/h $(5 \mu \mathrm{g} / 100 \mathrm{ml})$, normal $137-292 \mathrm{nmol} / 1(3 \cdot 5-7 \cdot 5 \mu \mathrm{g} / 100 \mathrm{ml})$ ) the hallucination continued. In 1976 she was reinvestigated. Her hallucinations had now disappeared and computed tomography showed a large empty sella and dilated lateral ventricles. We assumed that her tumour had undergone spontaneous infarction.

Case 3-A 71 year old woman presented in 1981 with five months' visual hallucinations of doctors and famous personalities, sometimes accompanied by unpleasant smells. These hallucinations had not occurred after cataract removals one and four years previously. She showed bilateral aphakia bitemporal hemianopia, and optic atrophy. Visual acuity was $6 / 12$ (right) and $3 / 60$ (left). Endocrine assessment showed plasma cortisol $196 \mathrm{nmol}$ $(7 \cdot 1 \mu \mathrm{g} / 100 \mathrm{ml})$ at $9 \mathrm{am}(170-720 \mu \mathrm{mol} / 1(6 \cdot 2-26 \cdot 1 \mu \mathrm{g} / 100 \mathrm{ml}))$ with corticotrophin of $76 \mathrm{ng} / 1(15-80)$, and thyroxine $54 \mathrm{nmol} / 1(4 \cdot 2 \mu \mathrm{g} / 100 \mathrm{ml}(50-150$ $\mathrm{nmol} / 1(3.9-11.7 \mu \mathrm{g} / 100 \mathrm{ml}))$ with thyroid stimulating hormone $3 \mathrm{IU} / 1(<6 \mathrm{IU})$

The prolactin concentration was raised at $1253 \mathrm{mU} / 1<350)$ while follicle stimulating hormone and luteinising hormone concentrations were low at 5 and $7 \mathrm{U} 1(>10$ and $>15$ postmenopause). Insulin tolerance testing was contraindicated because of her age. Computed tomography showed a pituitary tumour with a large suprasellar extension. A chromophobe adenoma was removed, with no immediate benefit. After external irradiation and treatment with chlorpromazine the hallucinations have improved but not disappeared.

\section{Comment}

Visual hallucinations occur in medical and psychiatric disorders, but are commoner in physical illness. ${ }^{*}$ Our patients had no evidence of psychiatric disorder and computed tomography excluded coincidental intracranial tumours and vascular accidents. A metabolic cause of the hallucinations seems unlikely: the borderline low cortisol concentrations in cases 1 and 3 were associated with no other features of hypoadrenalism, and although the second patient was treated with thyroxine there was no evidence of hypothyroidism at the time of hallucinations. Suprasellar extension occurred in all patients, with features of frontoparietal and temporal lobe dysfunction in cases 2 and 3. Since reduction in tumour size by surgery, irradiation, or spontaneous infarction was accompanied by complete or partial resolution of the hallucinations, a pressure effect of the tumour seems the likely mechanism for their occurrence. Formed visual hallucinations usually arise from the temporal or interpeduncular regions" but may be false localising symptoms of frontal or infratentorial lesions, " and this may account for our cases with no extension to the temporal lobes.

These cases strengthen the earlier report associating pituitary adenomas with visual hallucinations. ${ }^{1}$ All described cases have shown suprasellar extension threatening vision, and, since treatment with major tranquillisers may suppress symptoms, early recognition of the pituitary lesion is vital. A pituitary adenoma should be considered in any patient presenting with formed visual hallucinations.

Dr P K Robinson, formerly of the Wessex Neurological Centre, kindly granted permission to publish details of case 1 .

1 Weinberger LM, Grant FC. Visual hallucinations and their neuro-optical correlates. Arch Ophthalmol 1940;23:166-99.

2 Walsh FB, Hoyt F. Clinical neuro-ophthalmology. Vol 1. 3rd ed Baltimore W'illiams and W'ilkins, 1969:117.

3 Elkington SG. Pituitary adenoma. Pre-operative symptomatology in a series of 260 patients. Br F Ophthalmol 1968;52:322-8.

4 Hall RCW', Popkin MT, Devaul RA, Faillace LA, Stickney SK Physical illnes presenting as psychiatric disease. Arch Gen Psychiatry 1978;35:1315-20. 5 Anonymous. Localisation of visual hallucinations. Br.Med f 1977;i:147-8.

(Accepted 26 fune 1984

Departments of Endocrinology and Neurology, North Manchester General Hospital, Manchester M8 6RB

DAVID J DAWSON, BSC, MRCP, senior registrar in medicine

B ANTHONY ENOCH, BSC, FRCP, consultant physician

DAVID I SHEPHERD, MD, MRCP, consultant neurologist

Correspondence to: Dr D J Dawson. 